\title{
Oxygen isotope composition of diatoms as Late Holocene climate proxy at Two-Yurts Lake, Central Kamchatka, Russia
}

\author{
Hanno Meyer ${ }^{\mathrm{a}, *}$, Bernhard Chapligin a ${ }^{\mathrm{a}}$, Ulrike Hoff ${ }^{\mathrm{ab}}$, Larisa Nazarova ${ }^{\mathrm{a}, \mathrm{c}}$, Bernhard Diekmann ${ }^{\mathrm{a}}$ \\ a Alfred Wegener Institute Helmholtz Centre for Polar and Marine Research, Research Unit Potsdam, Telegrafenberg A43, 14473 Potsdam, Germany \\ b Department of Geology, University of Tromsø, Dramsveien 201, 9037 Tromsø, Norway \\ c Kazan Federal University, Kremlyovskaya 18, 420008 Kazan, Russia
}

\section{A R T I C L E I N F O}

\section{Article history:}

Received 8 November 2013

Received in revised form 31 March 2014

Accepted 28 April 2014

Available online $\mathrm{xxxx}$

\section{Keywords:}

Diatom oxygen isotopes

Biogenic silica

Holocene

Aleutian Low

Palaeoclimate

Palaeolimnology

\begin{abstract}
A B S T R A C T
Especially in combination with other proxies, the oxygen isotope composition of diatom silica $\left(\delta^{18} \mathrm{O}_{\text {diatom }}\right)$ from lake sediments is useful for interpreting past climate conditions. This paper presents the first oxygen isotope data of fossil diatoms from Kamchatka, Russia, derived from sediment cores from Two-Yurts Lake (TYL). For reconstructing Late Holocene climate change, palaeolimnological investigations also included diatom, pollen and chironomid analysis.

The most recent diatom sample $\left(\delta^{18} \mathrm{O}_{\text {diatom }}=+23.3 \%\right.$ ) corresponds well with the present day isotopic composition of the TYL water ( mean $\delta^{18} \mathrm{O}=-14.8 \%$ ) displaying a reasonable isotope fractionation in the system silicawater. Nonetheless, the TYL $\delta^{18} \mathrm{O}_{\text {diatom }}$ record is mainly controlled by changes in the isotopic composition of the lake water. TYL is considered as a dynamic system triggered by differential environmental changes closely linked with lake-internal hydrological factors.

The diatom silica isotope record displays large variations in $\delta^{18} \mathrm{O}_{\text {diatom }}$ from $+27.3 \%$ to $+23.3 \%$ from about $\sim 4.5 \mathrm{kyr}$ BP until today. A continuous depletion in $\delta^{18} \mathrm{O}_{\text {diatom }}$ of $4.0 \%$ is observed in the past $4.5 \mathrm{kyr}$, which is in good accordance with other hemispheric environmental changes (i.e. a summer insolation-driven Mid- to Late Holocene cooling). The overall cooling trend is superimposed by regional hydrological and atmospheric-oceanic changes. These are related to the interplay between Siberian High and Aleutian Low as well as to the ice dynamics in the Sea of Okhotsk. Additionally, combined $\delta^{18} \mathrm{O}_{\text {diatom }}$ and chironomid interpretations provide new information on changes related to meltwater input to lakes. Hence, this diatom isotope study provides further insight into hydrology and climate dynamics of this remote, rarely investigated area.
\end{abstract}

(c) 2014 Elsevier B.V. All rights reserved.

\section{Introduction}

Among terrestrial climate archives, lake sediments have great potential to provide high resolution and continuous information on environmental change (Leng and Barker, 2006). Multi-proxy studies of lake sediment cores contribute to the reconstruction of Late Quaternary climate from the terrestrial perspective allowing for correlation with continuous archives such as marine sediments (LR04 benthic stack: Lisiecki and Raymo, 2005) and ice cores of both hemispheres (i.e. NGRIP: Vinther et al., 2006; GISP2: Mayewski et al., 2004; EPICA Community, 2006). The use of oxygen isotopes in biogenic silica (diatoms) within aquatic sediments relates to milestone work by Labeyrie (1974) and Shemesh et al. (1992) and has become increasingly common since both, lacustrine and marine systems contain siliceous microfossils such as diatoms.

Diatoms are photosynthetic algae with cell walls composed of $\mathrm{SiO}_{2}$ with a characteristic morphology and two intricately-patterned valves.

\footnotetext{
* Corresponding author.

E-mail address: Hanno.Meyer@awi.de (H. Meyer).
}

Their ubiquitous growth in almost all aquatic environments make the analysis of fossil diatoms in lake sediments a particularly useful method for reconstructing spatial and temporal ecological, environmental and climate changes at the local to regional scale (Battarbee et al., 2005). However, it is difficult to estimate the exact palaeoenvironmental parameters from diatom species distribution.

The oxygen isotope composition of diatom frustules $\left(\delta^{18} \mathrm{O}_{\text {diatom }}\right)$ extracted from lacustrine sediments is used as a tool to assess changes in temperature, precipitation patterns, or evaporation in lacustrine ecosystems (Jones et al., 2004; Leng and Marshall, 2004; Leng and Barker, 2006). A substantial number of such records from different parts of the world underline the potential for reconstructing past climate changes from the oxygen isotope composition of biogenic silica $\left(\delta^{18} \mathrm{O}_{\mathrm{Si}}\right)$.

However, a suitable lake for palaeoclimate reconstruction with oxygen isotopes in biogenic silica needs to be hydrologically known (Leng and Barker, 2006) including recent information on lake water temperature and isotope composition of the lake. Did the lake dry out or change its level during geological periods? What is the input signal to the lake and how did it change through time? What is the seasonality of precipitation to the lake? What is the hydrological balance (open/closed 
system, inflow/outflow, residence time)? How well is the lake mixed in terms of lake water temperature and chemical composition?

Within the scope of the Russian-German project KALMAR ("KurileKamchatka and Aleutean Marginal Sea-Island Arc Systems: Geodynamic and Climate Interaction in Space and Time"), lake sediments and water samples were recovered from Two-Yurts Lake (TYL), Kamchatka to gain past environmental information. One main objective of the KALMAR project is to infer Late Quaternary climate change on Kamchatka on the basis of palaeolimnological records (Nazarova et al., 2013; Hoff et al., this issue).

We selected Two-Yurts Lake for our studies due to its setting, hydrological characteristics and readily available background information on important key parameters (i.e. sedimentology, age model). TYL sediments consist of diatom-rich oozes (interrupted by a few tephra layers) dominated by only a few diatom species (Hoff et al., this issue) yielding sufficiently high-purity diatom samples for oxygen isotope analyses. Additionally, diatom taxonomy and palynology (Hoff et al., this issue) as well as chironomids (Nazarova et al., 2013) were studied in parallel. Hence, the main aim of this study is to use diatom isotope signals of Two-Yurts Lake for Holocene palaeoenvironmental reconstruction, interpreted in comparison to local sedimentological, pollen and diatom assemblage data as well as to findings from TYL chironomid analyses as an independent temperature proxy. This regional environmental and climate information is then brought into the broader north hemispheric context to understand the linkage of Kamchatka to Holocene larger-scale climate patterns.

\section{Regional setting}

Two-Yurts Lake is situated at $56^{\circ} 49,2^{\prime} \mathrm{N} ; 160^{\circ} 06,3^{\prime} \mathrm{E}$ in the Central Mountain Chain of Kamchatka at an elevation of $275 \mathrm{~m}$ a.s.l. (above sea level). The Central Kamchatka Mountain Chain is mostly built of Neogene to mid-Pleistocene volcanic rocks and extinct volcanoes (Solomina et al., 2007).

Two-Yurts Lake is oval-shaped and covers an area of $11.7 \mathrm{~km}^{2}$ (Fig. 1). The mean water depth of this open through-flow lake system is about $25 \mathrm{~m}$. TYL formed on a moraine of the Two-Yurts Lake Valley, located on the eastern slope of the Central Kamchatka Mountain Chain. There are three main inflows to TYL at the western part and one outflow at the eastern side. The basin of Two-Yurts Lake is embedded in a former glacial valley at the eastern slope of Kamchatka's central mountain arc, the Sredinnyi Ridge. Mountain peaks and ridges closest to the lake reach about $1.100 \mathrm{~m}$ a.s.l. The local vegetation is characterised by stone birch forest and subalpine shrubs with dwarf birch and shrub pine (Krestov et al., 2008).

In the generally maritime setting of Kamchatka, the study area represents Kamchatka's most continental climate with coastal influence either from the Pacific side, about $150 \mathrm{~km}$ to the southeast, or from the Okhotsk Sea, $180 \mathrm{~km}$ to the west. The meteorological station at Petropavlovsk-Kamchatsky situated about $440 \mathrm{~km}$ to the SW of TYL yields an annual precipitation of $1335 \mathrm{~mm}$ and a mean annual air temperature (MAAT) of $+1.9{ }^{\circ} \mathrm{C}$ (Fig. 2). This station has been included in the Siberian Network of Isotopes in Precipitation (SNIP; Kurita et al., 2004) displaying mean annual oxygen and hydrogen isotope compositions of $-13.3 \%$ and $-100.7 \%$, respectively, with an overall low annual temperature and isotope variability typical of coastal stations (Fig. 2).

\section{Material and methods}

\subsection{Field work and age model}

In September 2007, six sediment cores were taken from TYL with a raft and a tripod-supported UWITEC-piston corer system. We refer to two overlapping sediment cores taken at site PG1857 (Fig. 1). Sediment core PG1857-2 includes the upper section downcore from the surface bottom sediment, which has been spliced at a 189-191 cm core depth to sediment core PG1857-5 at a 59-61 cm core depth to gather a $3.5 \mathrm{~m}$ long composite section. The TYL age model at site PG1857 relies upon nine radiocarbon dates carried out at Poznan Radiocarbon Laboratory, Poland and tephra layers related to a reference ash stratigraphy of Kamchatka (Dirksen et al., 2013). The radiocarbon dates of sediment core PG1857-2 range between 0.14 and 2.55 cal yr BP and those of
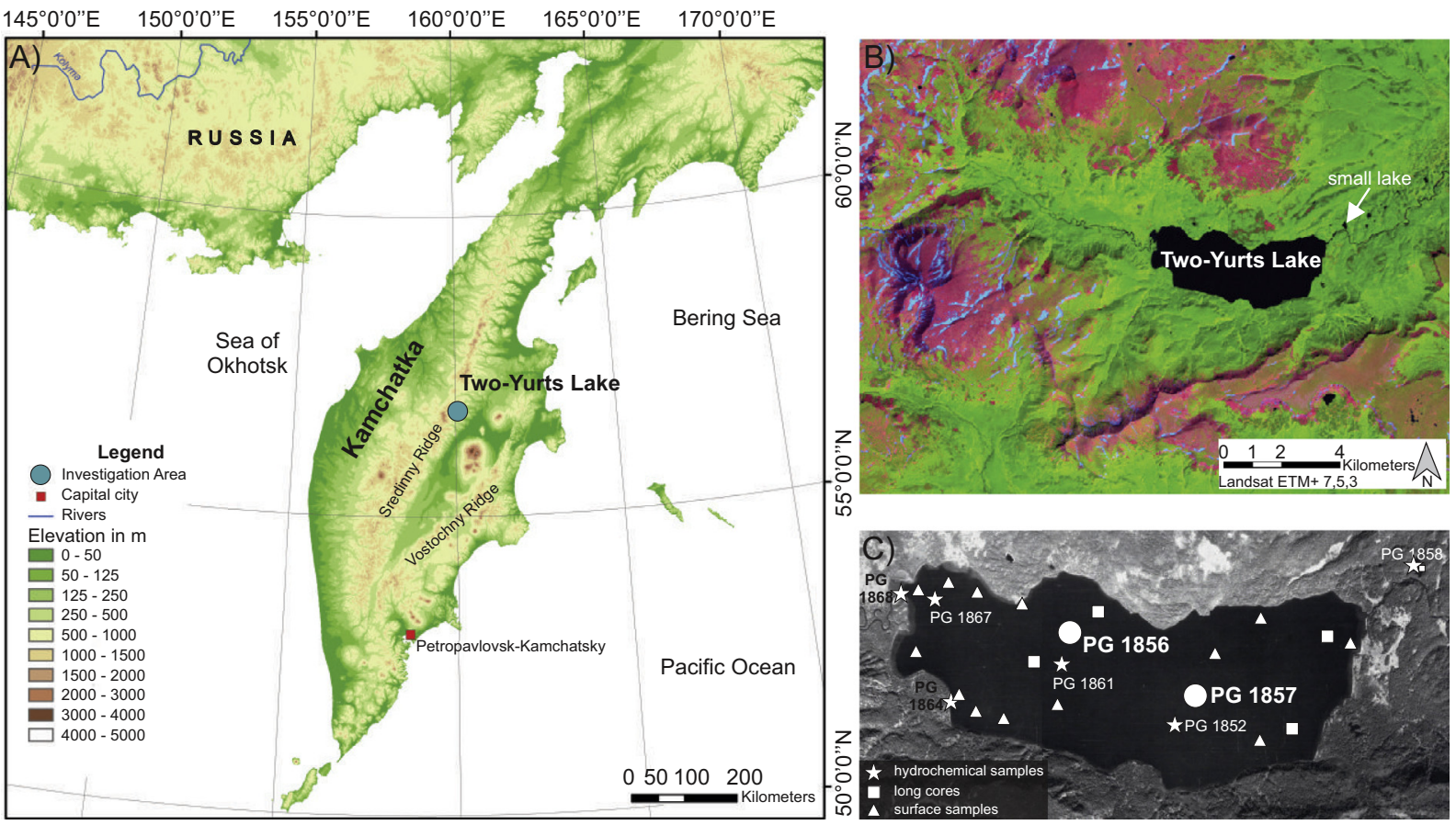

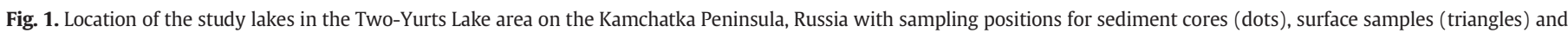
hydrochemical samples (asterisks). Note: a small lake near TYL has been sampled for comparison. 
core PG1857-5 between 2.57 and 4.47 cal yr BP. The criteria for splicing were related to sedimentological changes (i.e. ash layers) and radiocarbon data (two dates confirming each other). Further information about the age model is discussed in detail in Nazarova et al. (2013) and Hoff et al. (this issue).

Water samples were taken with a 1.5-liter UWITEC water sampler from the surface and in two depth profiles (PG1852-2; PG1861-1) in the middle of Two-Yurts Lake (Table 1). Additionally, samples from two inflows (PG1864-2; PG1868-2) as well as from a small, unnamed lake ca. $1 \mathrm{~km}$ to the east of TYL (PG1858-4) were retrieved.

\subsection{Water analysis}

During field work, water temperatures, oxygen concentrations, $\mathrm{pH}$ and electrical conductivities were measured directly after sampling with a WTW Multi 340i probe. Water samples were filtered through $0.45 \mu \mathrm{m}$ cellulose acetate filters for further major ion analysis and then subdivided for anion and cation analyses. Cation samples were then acidified with ultrapure nitric acid $\left(65 \% \mathrm{HNO}_{3}\right)$. Anion concentrations were determined using Ion Chromatography (IC, Dionex DX-320), cation concentrations by Inductively Coupled Plasma-Optical Emission Spectrometry (ICP-OES, Perkin-Elmer Optima 3000XL) and $\mathrm{HCO}^{-}$by titration to $\mathrm{pH} 4.3$ (Metrohm Basic Titrino 794). The analytical precision of major ion analyses is within $\pm 10 \%$.

The stable oxygen and hydrogen isotope compositions were measured using equilibration techniques and Finnigan MAT Delta-S mass-spectrometers (Meyer et al., 2000). They are given as $\delta$ values in per mil difference to V-SMOW (Vienna Standard Mean Ocean Water) with an analytical uncertainty $(1 \sigma)$ of better than $\pm 0.8 \%$ and $\pm 0.1 \%$ o for $\delta \mathrm{D}$ and $\delta^{18} \mathrm{O}$, respectively. All laboratory-based hydrochemical and stable isotope measurements were carried out at the Alfred Wegener Institute for Polar and Marine Research, Potsdam.

\subsection{Diatom taxonomy and purification for stable isotope analysis}

TYL sediment samples were freeze-dried and split into subsamples for micropalaeontological, sedimentological, and stable isotope studies. The sample preparation for quantitative diatom analyses (using light microscopy at $1000 \times$ magnification with a Zeiss AXIO A1 with an Achroplan $100 \times 1.4$ Oil Ph3-objective and scanning electron microscopy) as well as diatom counting are described in detail in Hoff et al. (2012; this issue). Due to the predominance of two diatom species (Aulacoseira subarctica (O. Müller) Haworth and Stephanodiscus minutulus (Kützing) Cleve \& Möller) in the samples of TYL we needed to count up to a number of 300 frustules including every diatom species except the dominant two species (which have been counted along).

Pure sample material is essential for analysing the isotopic composition of diatom frustules $\left(\delta^{18} \mathrm{O}_{\text {diatom }}\right)$. Therefore several physical and chemical preparation steps were conducted during the purification process based on Chapligin et al. (2012a): (1) organic matter and carbonates were removed by heating the sample to $50{ }^{\circ} \mathrm{C}$ for at least $20 \mathrm{~h}$, repeatedly adding concentrated hydrogen peroxide $\left(\mathrm{H}_{2} \mathrm{O}_{2}, 35 \%\right)$ and in a last step hydrochloric acid $(\mathrm{HCl}, 10 \%)$. Chemical remains were rinsed with ultrapure water. (2) Clay and fine silt were eliminated by sieving the sample with a $10 \mu \mathrm{m}$ sieve (hence, we refer to the size fraction $>10 \mu \mathrm{m}$ ). (3) Diatom frustules were further concentrated by heavy liquid separation with sodium polytungstate (SPT). This process was repeated 4 times with different solutions of decreasing density (2.4$2.2 \mathrm{~g} / \mathrm{cm}^{3}$ ), and SPT was discarded with ultrapure water. (4) Hardly soluble micro-organic coating or material trapped in the diatom frustules was removed by first heating the sample with ammonium chloride $\left(\mathrm{NH}_{4} \mathrm{Cl}\right)$ and acetic acid $\left(\mathrm{CH}_{3} \mathrm{COOH}\right)$ and then, with a mixture of nitric acid $\left(\mathrm{HNO}_{3}\right)$ and perchloric acid $\left(\mathrm{HClO}_{4}\right)$ before rinsing and drying the purified sample.

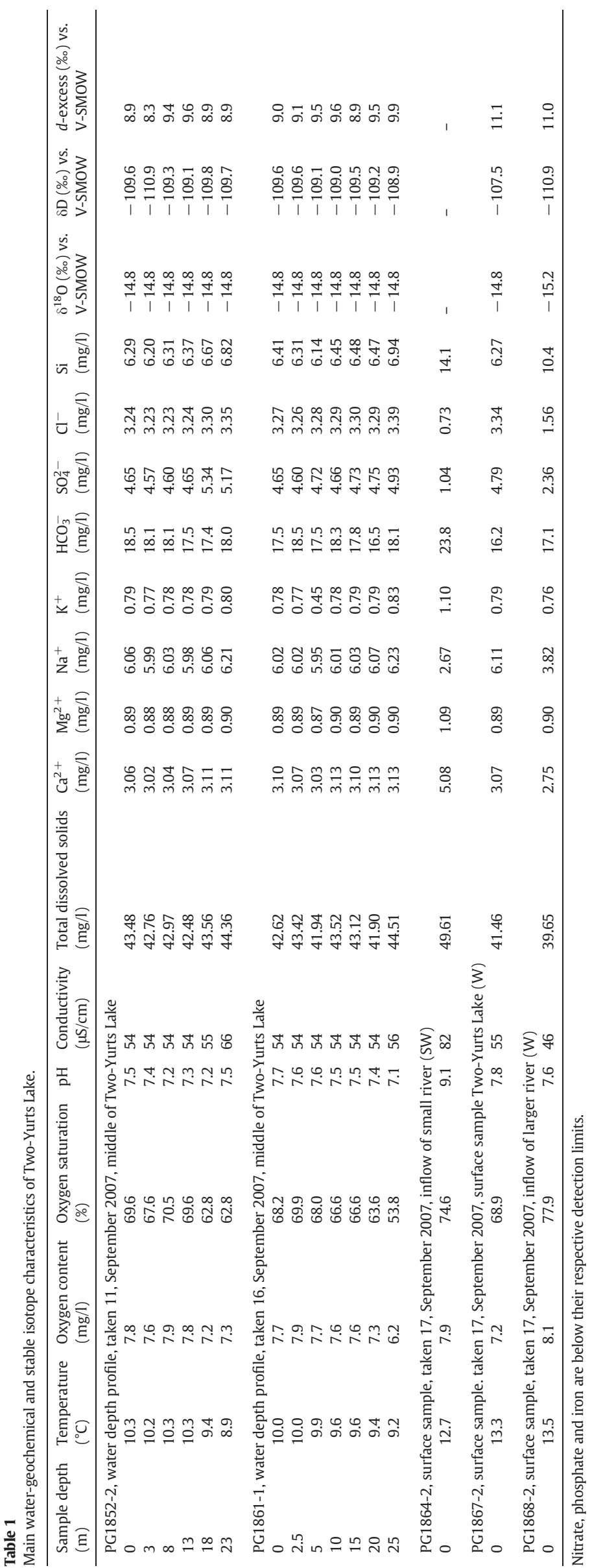




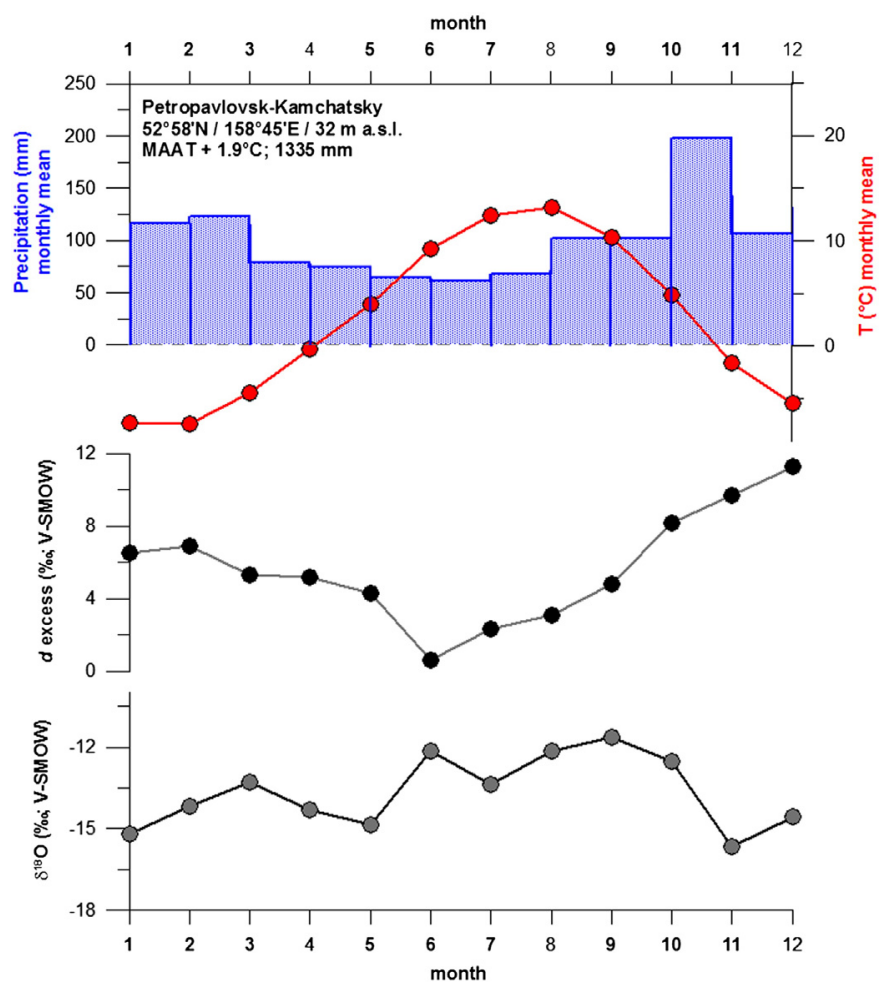

Fig. 2. Meteorological background data from Petropavlovsk-Kamchatsky (mean monthly temperature: red; mean monthly precipitation: blue). Additionally, the intra-annual variability of $\delta^{18} \mathrm{O}$ and $d$ excess for precipitation at this station are given. (For interpretation of the references to colours in this figure legend, the reader is referred to the web version of this article.)

\subsection{Stable isotope analysis}

Oxygen isotope analysis on biogenic silica was performed with a PDZ Europa 2020 mass spectrometer (MS-2020; now supplied by Sercon Ltd., UK) according to the method presented in Chapligin et al. (2010). Hydrous groups $\left(\mathrm{H}_{2} \mathrm{O},-\mathrm{OH}\right)$ were removed from clean diatom sample material ( 1.5 to $2 \mathrm{mg}$ ) using inert Gas Flow Dehydration (iGFD) in a horizontal ceramic tube furnace flushed with helium (Chapligin et al., 2010). The dehydrated sample was fully reacted by laser fluorination under $\mathrm{BrF}_{5}$ atmosphere to quantitatively generate $\mathrm{O}_{2}$ according to Sharp (1990). The $\mathrm{O}_{2}$ was separated from its byproducts (such as $\mathrm{SiF}_{4}$ ), trapped in a molecular sieve, then transferred to the mass spectrometer for oxygen isotope analysis. $20 \%$ of the samples were biogenic working standards to verify the accuracy of the isotope analyses. We used the lacustrine diatom standard BFC calibrated within an inter-laboratory comparison (Chapligin et al., $2011)$ to $+29.0 \pm 0.3 \%$. Additionally, the international quartz standard NBS28 ( $\delta^{18} \mathrm{O}=+9.57 \%$; Hut, 1987 ; Gröning et al., 2007) was used. The long-term performance of $\delta^{18} \mathrm{O}$ values in silica displays standard deviations of $1 \sigma \leq 0.15 \%$ of quartz and $1 \sigma \leq 0.25 \%$ for biogenic silica standards (Chapligin et al., 2010). Duplicate oxygen isotope analyses were performed for 13 TYL samples yielding a mean standard deviation of $0.21 \%$ o $(1 \sigma)$.

\subsection{Contamination assessment and correction}

The measured oxygen isotope composition $\left(\delta^{18} \mathrm{O}_{\text {measured }}\right)$ was corrected (to $\delta^{18} \mathrm{O}_{\text {corr }}$ ) using geochemical mass-balancing (Brewer et al., 2008; improved by Swann and Leng, 2009; Chapligin et al., 2012a).

$\delta^{18} \mathrm{O}_{\text {corr }}=\left(\delta^{18} \mathrm{O}_{\text {measured }}-\%\right.$ cont. $\left.* \delta^{18} \mathrm{O}_{\text {cont. }}\right) / \%$ purity where the percentage of purity was $100 \%$ subtracted by the percentage of remaining contamination (\%cont.). Accordingly, \%cont. was calculated by dividing the sample percentage of $\mathrm{Al}_{2} \mathrm{O}_{3}$ by the $\mathrm{Al}_{2} \mathrm{O}_{3}$ percentage from a $100 \%$ contamination end member according to Brewer et al. (2008), Swann et al. (2008) and Mackay et al. (2011). $\mathrm{Al}_{2} \mathrm{O}_{3}$ percentages for each sample were analysed by Energydispersive X-ray Spectroscopy (EDS) (3-5 repetitions, diameter of excited-area size: $100-120 \mu \mathrm{m})$. Finally, the \%cont. and $\delta^{18} \mathrm{O}_{\text {corr }}$ were calculated using the end-members $\delta^{18} \mathrm{O}_{\text {cont. }}=+7.34 \%$ and $\mathrm{Al}_{2} \mathrm{O}_{3 \text { cont. }}=15 \%$ (Chapligin et al., 2012a). In Table 2, the results of the EDS analyses are summarized showing the geochemical characteristics of diatoms at TYL. The high purity in the diatom samples at TYL is documented by $\mathrm{SiO}_{2}$ concentrations always $>98.1 \%$ ( $>99 \%$ in 29 out of 42 samples) and $\mathrm{Al}_{2} \mathrm{O}_{3}<0.9 \%(<0.3 \%$ in 34 out of 42 samples). This leads to a small mean correction value for $\delta^{18} \mathrm{O}_{\text {measured }}$ compared to $\delta^{18} \mathrm{O}_{\text {cont }}$ of $+0.28 \%$ and did not change the overall course of the measured TYL diatom isotope record (Fig. 4). Only at around $3.5 \mathrm{kyr} \mathrm{BP}$, the contamination is slightly higher ( $\max . \delta^{18} \mathrm{O}$ correction of $+1.0 \%$ ), which smoothened the $\delta^{18} \mathrm{O}_{\text {corr }}$ record (Fig. 4 , Table 2). In the following, we refer to $\delta^{18} \mathrm{O}_{\text {corr }}$ when interpreting $\delta^{18} \mathrm{O}_{\text {diatom }}$ in detail. Furthermore, as Kamchatka is known as a volcanically strongly active region, contamination with tephra needs to be taken into account when interpreting $\delta^{18} \mathrm{O}_{\text {diatom }}$ records. Lamb et al. (2007) describe several methods of assessing tephra contamination including light microscopy as well as geochemistry, i.e. $\mathrm{K}_{2} \mathrm{O}$ concentrations below $0.1 \%$ (which comprises all our samples except one). We therefore assume our samples as clean without major tephra sherd contamination. This is further substantiated by careful examination under the SEM (Fig. 5).

\section{Results}

\subsection{Water analysis}

Two water-depth profiles (PG1852-2 and PG1861-1) were taken in the centre of TYL on 11 and 16 September 2007, respectively (Table 1). The lake water temperatures varied between 8.9 and $10.3{ }^{\circ} \mathrm{C}$ and were similar in both profiles. The TYL water shows fresh-water conditions with low salinity (total dissolved ions: $40-44 \mathrm{mg} / \mathrm{l}$, conductivity: $\pm 54 \mu \mathrm{S} / \mathrm{cm}$ ) and an ion composition with $\mathrm{Na} \gg \mathrm{Ca} \gg \mathrm{Mg} \geq \mathrm{K}$, and $\mathrm{HCO}_{3} \gg \mathrm{SO}_{4} \geq \mathrm{Cl}$ (Table 1 ), pointing to waters supplied by river runoff and precipitation (e.g. Wetzel, 2001). Overall high Si concentrations $(\geq 6.0 \mathrm{mg} / \mathrm{l}$ ) reflect the presence of volcanic rocks and soils in the catchment, which are prone to leaching.

The results of stable water isotope analyses are summarized in Table 1 and presented in a $\delta^{18} \mathrm{O}-\delta \mathrm{D}$ diagram (Fig. 3) with respect to the Global Meteoric Water Line (GMWL; $\left.\delta \mathrm{D}=8 \cdot \delta^{18} \mathrm{O}+10\right)$, in which fresh surface waters (Craig, 1961) are correlated on a global scale. Modern TYL water depth profiles show a constant isotopic composition of $\delta^{18} \mathrm{O}_{\text {lake }}=-14.8 \%$; $\delta D_{\text {lake }}=-110 \%$ and $d$ excess lake $=9.5 \%$, respectively. These values point to a well-mixed water column lacking any isotopic stratification, at least in late summer 2007 (compare Table 1). The strong wind activity during field work and uniform hydrochemical parameters in the water column substantiate this assumption. TYL water isotope data are situated close to the Global Meteoric Water Line (GMWL) (Fig. 3), suggesting the absence of evaporation effects. In contrast, a smaller closed-system lake near TYL shows a marked offset from the GMWL (Fig. 1 and 3) indicative of evaporation effects. The two main river inflows display slightly higher temperatures than the lake $\left(12.7-13.5^{\circ} \mathrm{C}\right)$, with a chemical composition roughly consistent with the lake-water chemistry (Table 1). Since the stable isotope composition of one inflow ( $\delta^{18} \mathrm{O}=-15.2 \%$; $\delta \mathrm{D}=-110.9 \%$ ) is also similar to that of the TYL water, we assume that the tributaries contribute a significant amount of water and ions to TYL.

During the field campaign in 2007, it did not rain and no precipitation samples could be taken. Therefore, the oxygen and hydrogen 
Table 2

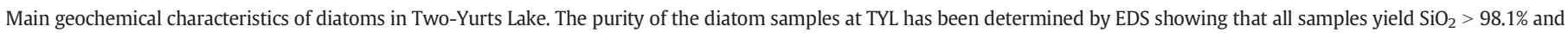
$\mathrm{Al}_{2} \mathrm{O}_{3}<0.9 \%$. Additionally, measured $\delta^{18} \mathrm{O}$ values $\left(\delta^{18} \mathrm{O}_{\text {measured }}\right.$ ), calculated contamination (cCont; \%) and $\delta^{18} \mathrm{O}$ values corrected for contamination $\left(\delta^{18} \mathrm{O}_{\text {corr }}\right)$ are given.

\begin{tabular}{|c|c|c|c|c|c|c|c|c|c|c|c|c|c|}
\hline Core & $\begin{array}{l}\text { Sample depth } \\
(\mathrm{cm})\end{array}$ & $\begin{array}{l}\mathrm{SiO}_{2} \\
(\%)\end{array}$ & $\begin{array}{l}\mathrm{Na}_{2} \mathrm{O} \\
(\%)\end{array}$ & $\begin{array}{l}\mathrm{MgO} \\
(\%)\end{array}$ & $\begin{array}{l}\mathrm{Al}_{2} \mathrm{O}_{3} \\
(\%)\end{array}$ & $\begin{array}{l}\mathrm{K}_{2} \mathrm{O} \\
(\%)\end{array}$ & $\begin{array}{l}\mathrm{TiO}_{2} \\
(\%)\end{array}$ & $\begin{array}{l}\mathrm{Fe}_{2} \mathrm{O}_{3} \\
(\%)\end{array}$ & $\begin{array}{l}\mathrm{CaO} \\
(\%)\end{array}$ & Total & $\begin{array}{l}\delta^{18} \mathrm{O}_{\text {measured }} \\
{[\% \text {; V-SMOW] }}\end{array}$ & $\begin{array}{l}\text { cCont } \\
{[\%]}\end{array}$ & $\begin{array}{l}\delta^{18} \mathrm{O}_{\text {corr }} \\
{[\% \text {; V-SMOW] }}\end{array}$ \\
\hline PG 1857-2 & $2.5-5$ & 99.28 & 0.18 & 0.03 & 0.04 & 0.01 & 0.01 & 0.44 & 0.00 & 100.0 & 23.34 & 0.27 & 23.38 \\
\hline PG 1857-2 & $9-12$ & 99.02 & 0.44 & 0.05 & 0.09 & 0.01 & 0.01 & 0.39 & 0.00 & 100.0 & 23.22 & 0.61 & 23.32 \\
\hline PG 1857-2 & $29-32$ & 99.18 & 0.38 & 0.05 & 0.18 & 0.00 & 0.03 & 0.19 & 0.00 & 100.0 & 23.78 & 1.19 & 23.98 \\
\hline PG 1857-2 & $39-41.5$ & 99.24 & 0.21 & 0.06 & 0.18 & 0.00 & 0.02 & 0.29 & 0.00 & 100.0 & 24.12 & 1.21 & 24.32 \\
\hline PG 1857-2 & $49-52$ & 99.27 & 0.05 & 0.06 & 0.27 & 0.03 & 0.01 & 0.28 & 0.09 & 100.1 & 23.53 & 1.79 & 23.82 \\
\hline PG 1857-2 & $58-61$ & 98.17 & 1.32 & 0.07 & 0.09 & 0.03 & 0.00 & 0.33 & 0.00 & 100.0 & 24.33 & 0.63 & 24.44 \\
\hline PG 1857-2 & $69-71.5$ & 98.48 & 0.96 & 0.06 & 0.15 & 0.01 & 0.00 & 0.33 & 0.00 & 100.0 & 24.25 & 0.99 & 24.42 \\
\hline PG 1857-2 & $79-82.5$ & 99.32 & 0.17 & 0.06 & 0.13 & 0.00 & 0.00 & 0.32 & 0.00 & 100.0 & 24.37 & 0.85 & 24.52 \\
\hline PG 1857-2 & $89-92.5$ & 99.30 & 0.15 & 0.07 & 0.17 & 0.04 & 0.00 & 0.28 & 0.00 & 100.0 & 24.41 & 1.12 & 24.60 \\
\hline PG $1857-2$ & 99-102.5 & 99.07 & 0.32 & 0.06 & 0.15 & 0.02 & 0.04 & 0.34 & 0.00 & 100.0 & 24.34 & 0.99 & 24.51 \\
\hline PG 1857-2 & $109-113$ & 99.00 & 0.18 & 0.06 & 0.21 & 0.02 & 0.06 & 0.46 & 0.00 & 100.0 & 24.79 & 1.43 & 25.04 \\
\hline PG 1857-2 & 119-122 & 98.79 & 0.47 & 0.12 & 0.20 & 0.01 & 0.05 & 0.37 & 0.00 & 100.0 & 24.89 & 1.34 & 25.13 \\
\hline PG 1857-2 & 129-132 & 99.22 & 0.44 & 0.05 & 0.11 & 0.02 & 0.00 & 0.18 & 0.00 & 100.0 & 24.74 & 0.76 & 24.87 \\
\hline PG $1857-2$ & $139-142$ & 99.17 & 0.28 & 0.03 & 0.18 & 0.04 & 0.00 & 0.30 & 0.00 & 100.0 & 24.92 & 1.21 & 25.13 \\
\hline PG 1857-2 & $149-151.5$ & 99.19 & 0.27 & 0.06 & 0.20 & 0.00 & 0.03 & 0.25 & 0.00 & 100.0 & 24.70 & 1.32 & 24.93 \\
\hline PG 1857-2 & $158-160.5$ & 99.30 & 0.20 & 0.05 & 0.17 & 0.00 & 0.02 & 0.26 & 0.00 & 100.0 & 24.80 & 1.14 & 25.00 \\
\hline PG 1857-2 & $169.5-171.5$ & 98.77 & 0.57 & 0.08 & 0.24 & 0.02 & 0.02 & 0.30 & 0.00 & 100.0 & 25.26 & 1.59 & 25.54 \\
\hline PG 1857-2 & $178.5-181$ & 99.31 & 0.10 & 0.07 & 0.14 & 0.02 & 0.03 & 0.33 & 0.00 & 100.0 & 25.11 & 0.94 & 25.28 \\
\hline PG 1857-2 & 189-191 & 98.48 & 0.53 & 0.06 & 0.35 & 0.04 & 0.06 & 0.45 & 0.12 & 100.0 & 24.64 & 2.35 & 25.05 \\
\hline PG 1857-2 & $200-202.5$ & 99.25 & 0.22 & 0.09 & 0.16 & 0.00 & 0.02 & 0.23 & 0.10 & 100.0 & 25.75 & 1.05 & 25.95 \\
\hline PG 1857-2 & $209-211.5$ & 98.85 & 0.50 & 0.06 & 0.19 & 0.00 & 0.03 & 0.37 & 0.00 & 100.0 & 25.81 & 1.30 & 26.05 \\
\hline PG 1857-2 & 219-221.5 & 98.70 & 0.33 & 0.06 & 0.44 & 0.05 & 0.06 & 0.35 & 0.00 & 100.0 & 25.44 & 2.98 & 25.99 \\
\hline PG 1857-2 & $229.5-231.5$ & 98.47 & 0.51 & 0.07 & 0.54 & 0.00 & 0.08 & 0.33 & 0.00 & 100.0 & 25.5 & 3.65 & 26.15 \\
\hline PG 1857-5 & $3.5-5$ & 98.73 & 0.56 & 0.05 & 0.28 & 0.03 & 0.02 & 0.32 & 0.00 & 100.0 & 25.40 & 1.91 & 25.74 \\
\hline PG 1857-5 & 9-11 & 99.28 & 0.22 & 0.06 & 0.15 & 0.01 & 0.04 & 0.23 & 0.00 & 100.0 & 25.16 & 0.99 & 25.34 \\
\hline PG 1857-5 & $17.5-19.5$ & 99.20 & 0.16 & 0.05 & 0.22 & 0.03 & 0.03 & 0.30 & 0.00 & 100.0 & 25.28 & 1.50 & 25.55 \\
\hline PG 1857-5 & $21-23$ & 99.22 & 0.23 & 0.04 & 0.20 & 0.00 & 0.04 & 0.27 & 0.00 & 100.0 & 24.99 & 1.34 & 25.23 \\
\hline PG 1857-5 & $29-31$ & 99.30 & 0.20 & 0.06 & 0.14 & 0.02 & 0.12 & 0.17 & 0.00 & 100.0 & 24.87 & 0.92 & 25.03 \\
\hline PG 1857-5 & $39-41$ & 98.87 & 0.29 & 0.03 & 0.13 & 0.06 & 0.12 & 0.50 & 0.00 & 100.0 & 25.10 & 0.90 & 25.26 \\
\hline PG 1857-5 & $49-51$ & 99.00 & 0.22 & 0.07 & 0.16 & 0.07 & 0.21 & 0.27 & 0.00 & 100.0 & 25.63 & 1.08 & 25.83 \\
\hline PG 1857-5 & $59-61$ & 99.10 & 0.16 & 0.06 & 0.21 & 0.06 & 0.12 & 0.28 & 0.00 & 100.0 & 26.05 & 1.43 & 26.32 \\
\hline PG 1857-5 & $69-71.5$ & 99.13 & 0.38 & 0.05 & 0.21 & 0.06 & 0.04 & 0.12 & 0.00 & 100.0 & 25.82 & 1.39 & 26.07 \\
\hline PG 1857-5 & $79-81$ & 99.13 & 0.38 & 0.05 & 0.21 & 0.06 & 0.04 & 0.12 & 0.00 & 100.0 & 25.08 & 1.39 & 25.33 \\
\hline PG 1857-5 & 89-91 & 99.37 & 0.07 & 0.04 & 0.21 & 0.04 & 0.04 & 0.23 & 0.00 & 100.0 & 25.42 & 1.41 & 25.68 \\
\hline PG 1857-5 & 99-101 & 99.03 & 0.51 & 0.03 & 0.04 & 0.00 & 0.13 & 0.25 & 0.00 & 100.0 & 25.49 & 0.27 & 25.54 \\
\hline PG 1857-5 & $109-111$ & 98.35 & 0.62 & 0.00 & 0.67 & 0.08 & 0.20 & 0.08 & 0.00 & 100.0 & 25.36 & 4.51 & 26.21 \\
\hline PG 1857-5 & $118.5-120$ & 98.19 & 0.10 & 0.16 & 0.56 & 0.16 & 0.05 & 0.78 & 0.00 & 100.0 & Not analysed & 3.77 & Not analysed \\
\hline PG 1857-5 & $120.5-123$ & 98.43 & 0.38 & 0.08 & 0.51 & 0.07 & 0.08 & 0.44 & 0.00 & 100.0 & Not analysed & 3.43 & Not analysed \\
\hline PG 1857-5 & $129-131.5$ & 98.23 & 0.39 & 0.14 & 0.81 & 0.03 & 0.00 & 0.40 & 0.00 & 100.0 & 25.00 & 5.45 & 26.01 \\
\hline PG 1857-5 & $139-141.5$ & 99.35 & 0.09 & 0.11 & 0.33 & 0.01 & 0.04 & 0.06 & 0.00 & 100.0 & 26.78 & 2.20 & 27.21 \\
\hline PG $1857-5$ & $149-152$ & 99.18 & 0.02 & 0.06 & 0.21 & 0.00 & 0.09 & 0.43 & 0.00 & 100.0 & 26.49 & 1.41 & 26.76 \\
\hline PG 1857-5 & $159-162$ & 99.44 & 0.06 & 0.09 & 0.17 & 0.03 & 0.00 & 0.21 & 0.00 & 100.0 & Not analysed & 1.17 & Not analysed \\
\hline PG 1857-5 & $169-172.5$ & 98.56 & 0.43 & 0.11 & 0.38 & 0.02 & 0.06 & 0.45 & 0.00 & 100.0 & Not analysed & 2.56 & Not analysed \\
\hline PG 1857-5 & 179-182 & 98.96 & 0.26 & 0.04 & 0.22 & 0.07 & 0.05 & 0.39 & 0.00 & 100.0 & 27.02 & 1.50 & 27.32 \\
\hline PG 1857-5 & 189-192.5 & 99.23 & 0.13 & 0.01 & 0.31 & 0.00 & 0.05 & 0.26 & 0.00 & 100.0 & 26.17 & 2.08 & 26.57 \\
\hline PG 1857-5 & 199.5-202.5 & 99.04 & 0.20 & 0.07 & 0.46 & 0.02 & 0.02 & 0.18 & 0.00 & 100.0 & 26.65 & 3.09 & 27.26 \\
\hline
\end{tabular}

isotope composition of precipitation $\left(\delta^{18} \mathrm{O}_{\text {prec }} ; \delta \mathrm{D}_{\text {prec }}\right)$ for Kamchatka has been derived from the GNIP database (IAEA/WMO, 2013). The mean annual isotopic composition of precipitation at PetropavlovskKamchatsky (WMO 3258300, N52 $58^{\prime} 48$; E $158^{\circ} 39^{\prime} 00$, height $24 \mathrm{~m}$ a.s.l.) is $\delta^{18} \mathrm{O}_{\text {prec }}=-13.5 \pm 0.8 \%$ (GNIP), which is only slightly higher (heavier) than the Two-Yurts Lake $\delta^{18} \mathrm{O}$ lake water with $-14.8 \%$ o (located further inland at $280 \mathrm{~m}$ a.s.l.). Additionally, $\delta^{18} \mathrm{O}_{\text {lake }}$ plots near the local meteoric water line (LMWL) based on mean monthly precipitation at Petropavlovsk-Kamchatsky $\left(\delta \mathrm{D}=6.72 \delta^{18} \mathrm{O}\right.$ - 11.7\%; Figs. 2 and 3), but here rather corresponds to cold seasons $\delta^{18} \mathrm{O}_{\text {prec. }}$. Thus, we assume, that $\delta^{18} \mathrm{O}_{\text {lake }}$ in fact should roughly correspond to $\delta^{18} \mathrm{O}_{\text {prec}}$, potentially biased to slightly more negative values (lighter) due to higher continentality and/or altitude of TYL or due to seasonality effects.

\subsection{Diatom analysis}

Within the sediments of the Two-Yurts Lake, 131 diatom species were identified (Hoff et al., this issue). The most abundant species throughout the core were $A$. subarctica and $S$. minutulus reaching maximum abundances of $58.2 \%$ and $66.1 \%$, respectively (Fig. 4). Only four other species have relatively high abundances: Stephanodiscus medius Håkansson (max. 13.8\%), Cyclotella ocellata Pantoçsek (max. 18.5\%), Stephanodiscus alpinus Hustedt (max. 4.1\%) and A. subarctica f. recta (O. Müller) Krammer (max. 3.7\%). A multivariate, depth-constrained cluster analysis was performed leading to a differentiation into five diatom assemblage zones (DAZ 1-5; Fig. 4; further details in Hoff et al., this issue). Since the first DAZ involves diatoms below a hiatus, they have not been used in this paper. We therefore discuss DAZ 2 to 5 only. DAZ 2 is characterised by the highest abundances in A. subarctica and $S$. medius only being present in this zone. DAZ 3 contains high abundances of $S$. alpinus, whereas $S$. medius and C. ocellata are present in only very small abundances. DAZ 4 displays the highest abundances for $C$. ocellata, which is only present in this interval. The uppermost DAZ 5 is characterised by the highest abundances of A. subarctica f. recta.

\subsection{Stable oxygen isotopes in diatoms}

The $\delta^{18} \mathrm{O}_{\text {diatom }}$ record (Fig. 4) exhibits varying isotopic compositions between $+23.3 \%$ and $+27.3 \%$. The oldest part of the core displays the highest $\delta^{18} \mathrm{O}_{\text {diatom }}$ values (>3.6 kyr BP; mean $\delta^{18} \mathrm{O}_{\text {diatom }}=+27.0 \%$; $\mathrm{N}=5$ ) and can be distinguished from the middle (3.6-1.8 kyr BP; 


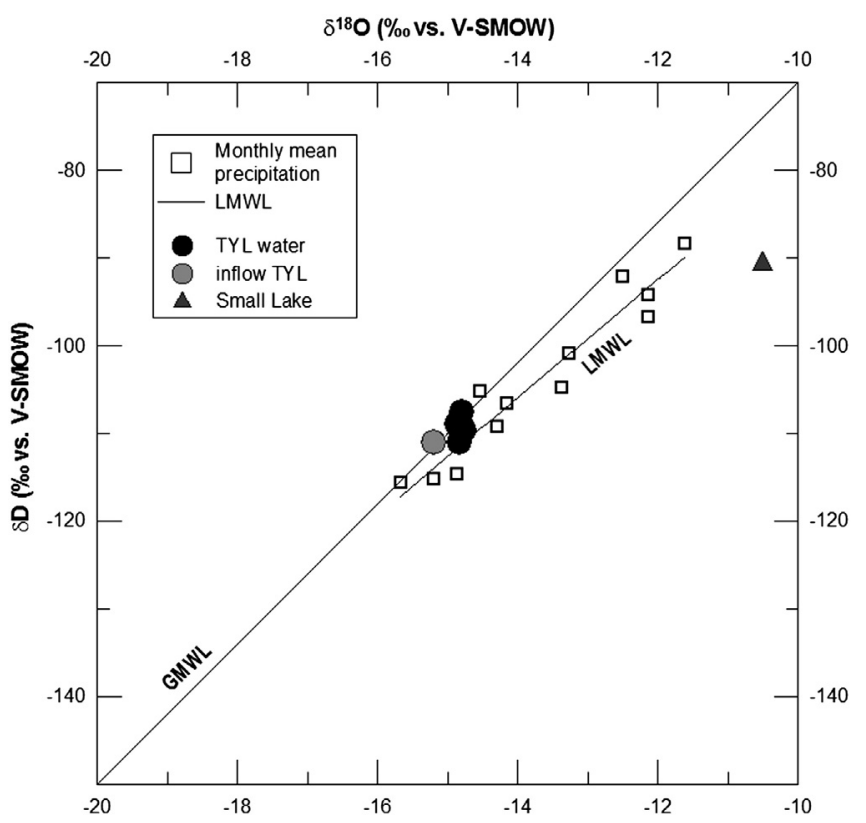

Fig. 3. $\delta^{18} \mathrm{O}-\delta \mathrm{D}$ diagram for Two Yurts Lake (black dot), inflow to TYL (grey dot) and small lake near TYL (black triangle) as summarized in Table 1. Additionally, the Global Meteoric Water Line (GMWL) as well as the GNIP data for mean monthly precipitation at Petropavlovsk-Kamchatsky, and the resulting local meteoric water line (LMWL) for precipitation are given.

mean $\left.\delta^{18} \mathrm{O}_{\text {diatom }}=+25.5 \% ; \mathrm{N}=27\right)$ and the younger parts $(<1.8 \mathrm{kyr}$ $\mathrm{BP}$; mean $\delta^{18} \mathrm{O}_{\text {diatom }}=+24.3 \%$; $\mathrm{N}=9$ ) of the record. Roughly, the lower part of the record is characterised by $\delta^{18} \mathrm{O}_{\text {diatom }}$ of $>+26.5 \%$; the middle section of between +24.5 and $+26.5 \%$ ond the uppermost part of the investigated cores by the lowest $\delta^{18} \mathrm{O}_{\text {diatom }}$ values of $<+24.5 \%$. Accordingly, the TYL diatom isotope record is characterised by an overall decreasing $\delta^{18} \mathrm{O}_{\text {diatom }}$ trend with time to $+23.3 \%$ or for the topmost two samples, corresponding to a decrease of approximately $-0.8 \%$ / kyr between $\sim 4.5 \mathrm{kyr}$ BP and today.

\section{Discussion}

\subsection{Stable oxygen isotope signals in diatoms}

The oxygen isotope composition of lacustrine diatom silica $\left(\delta^{18} \mathrm{O}_{\text {diatom }}\right)$ is controlled by several interacting environmental factors (Leng and Barker, 2006). These factors comprise lake water temperature ( $\mathrm{T}_{\text {lake }}$ ), disequilibrium ("vital") effects as well as the isotopic composition of the lake water $\left(\delta^{18} \mathrm{O}_{\text {lake }}\right)$ being affected by precipitation and further hydrological parameters (i.e. evaporation and inflow/outflow ratio).

\subsubsection{Lake water temperature}

The $\delta^{18} \mathrm{O}_{\text {diatom }}$ composition is strongly dependent on $\mathrm{T}_{\text {lake }}$ during diatom growth (Brandriss et al., 1998; Schmidt et al., 2001; Dodd and Sharp, 2010). The temperature relationship of the silica-water fractionation is described with a relatively constant $\delta^{18} \mathrm{O}$-temperature coefficient of $-0.2 \% /{ }^{\circ} \mathrm{C}$ (Dodd et al., 2012). Several experimental studies describe the temperature-dependency of the silica-water fractionation, expressed in different fractionation factors ( $\alpha$ (silica-water); e.g. Juillet-Leclerc and Labeyrie, 1987; Dodd and Sharp, 2010). A compilation of different fractionation factors (Dodd et al., 2012), leads to an average $\alpha$ (silica-water) value of $1.038 \pm 0.004$, taking under consideration isotopic fractionation at a modern Two-Yurts Lake water temperature of $\sim 10{ }^{\circ} \mathrm{C}$ (as measured in the field). Based on this, the measured $\delta^{18} \mathrm{O}_{\text {diatom }}$ of $\sim+23 \%$ leads to an expected modern lake water isotopic composition of Two-Yurts Lake of $\delta^{18} \mathrm{O}_{\text {lake }} \sim-15 \pm 2 \%$, which corresponds well to the measured $\delta^{18} \mathrm{O}_{\text {lake }}$ of $-14.8 \%$. Consequently, the uppermost sample of core PG1857, as the most recent sample, displays a $\delta^{18} \mathrm{O}_{\text {diatom }}$ of about $+23.3 \%$ o coinciding with the present day isotopic composition of the TYL.

However, the temperature of the lake water alone can be excluded as a controlling factor on the changing oxygen isotope composition of the TYL diatoms. Following the $\delta^{18} \mathrm{O}_{\text {diatom }}-\mathrm{T}_{\text {lake }}$ correlation (Brandriss et al., 1998), such a wide isotopic range of $\Delta^{18} \mathrm{O}=4.0 \%$. would be equivalent to a $\mathrm{T}_{\text {lake }}$ difference of up to $\sim 20{ }^{\circ} \mathrm{C}$ lower temperature and, hence, would correspond to negative $\mathrm{T}_{\text {lake. }}$. Although some diatom species are able to grow even under lake ice cover, even well adapted diatoms are not able to grow in large amounts in TYL in a hypothetically frozen milieu. Particularly, the Late Holocene is known to have been a rather warm period verified by different proxy studies, though not reaching temperatures of the mid-Holocene Climate Optimum. Furthermore, the spliced sections of the core delineate an overall decreasing trend in $\delta^{18} \mathrm{O}_{\text {diatom }}$ values. In general such a decreasing trend in $\delta^{18} \mathrm{O}_{\text {diatom }}$ values with time would infer increasing $\mathrm{T}_{\text {lake, }}$ assuming that $\mathrm{T}_{\text {lake }}$ would be the major determining factor for the isotopic composition of the $\delta^{18} \mathrm{O}_{\text {diatom }}$ record. Since this scenario delineates the opposite of what is known about the mid- and Late Holocene of Kamchatka, we assume a minor relevance of the lake water temperature changes for the $\delta^{18} \mathrm{O}_{\text {diatom }}$ trend.

\subsubsection{Evaporation and hydrology}

Closed lake systems (such as the small lake presented in Figs. 1 and 3) are generally more influenced by evaporative effects than open throughflow systems, such as Two-Yurts Lake. Furthermore, enhanced evaporation would shift the isotopic composition of the remaining lake water towards more positive (isotopically heavier) values and below the Global Meteoric Water Line (GMWL). Such evaporative enrichment is not observed in the $\delta^{18} \mathrm{O}_{\text {lake }}$ of TYL (Table $1, \mathrm{~N}=15$ ), with measured $\delta^{18} \mathrm{O}_{\text {lake }}$ and $\delta \mathrm{D}_{\text {lake }}$ close to the GMWL (Fig. 3), indicating that presently evaporation does not remarkably affect the Two-Yurts Lake system. This assumption is supported by the modern water depth of $\sim 25 \mathrm{~m}$ and the geological setting of the lake. The recent water body is almost completely bordered by steep slopes, allowing for changes in the water depth without significant changes of the surface area of the lake. Nonetheless, there are at least two palaeo-lake terraces around TYL pointing to higher lake levels in the past (Dirksen et al., 2013), but spanning a small area only. The higher lake level might have resulted from landslides retaining the water, whereas shortly after these events retrograde erosion might have led to a lowering of the lake level. A significantly lower lake level in the past seems unlikely because bathymetric investigations provided no hints of fossil lake terraces situated under the recent lake level. Therefore, we assume no major variations in lake extent and depth. Hence, evaporation effects are assumed to be of minor importance at TYL and accordingly, we suggest the precipitation signal $\left(\delta^{18} \mathrm{O}_{\text {prec }}\right)$ to be most relevant for the isotopic composition of the lake water.

\subsubsection{Vital effects}

Although Swann et al. $(2007,2008)$ found a small vital effect (isotopic-species effect) in diatom oxygen isotopic composition, studies on both marine (Shemesh et al., 1995) and freshwater diatoms (Shemesh and Peteet, 1998; Rosqvist et al., 1999; Shemesh et al., 2001; Chapligin et al., 2012b), established that vital effects do not influence the isotopic composition of diatoms. As the Two-Yurts Lake contains predominantly two main diatom species (A. subarctica and S. minutulus) in the $>10 \mu \mathrm{m}$ fraction, which are consistently present throughout the core, we assume that $\delta^{18} \mathrm{O}_{\text {diatom }}$ is not being affected by isotopic-species effects. This is supported by the observation that none of the DAZ boundaries (Fig. 4) corresponds to major changes (i.e. minima/maxima) in the $\delta^{18} \mathrm{O}_{\text {diatom }}$ record. 


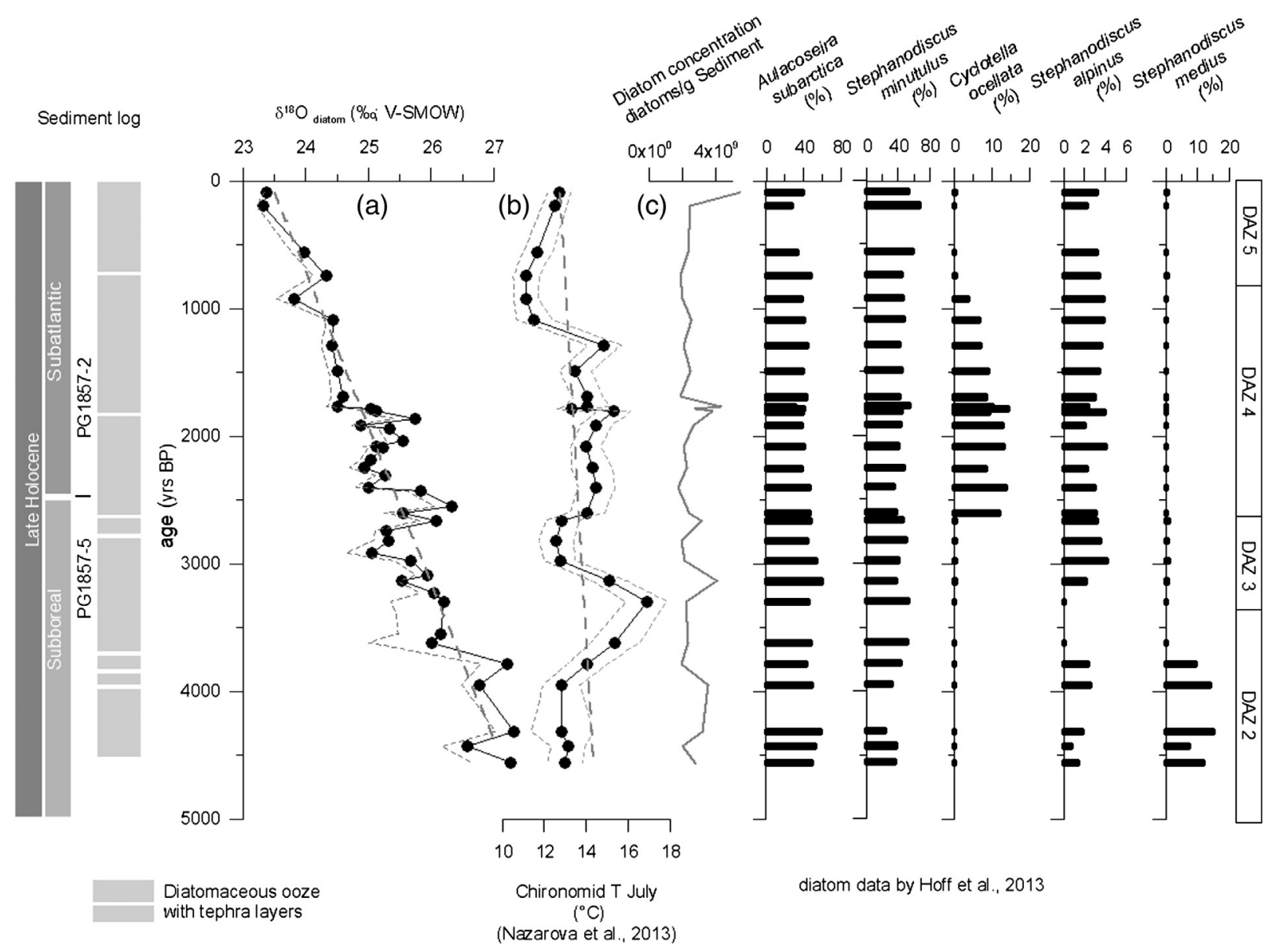

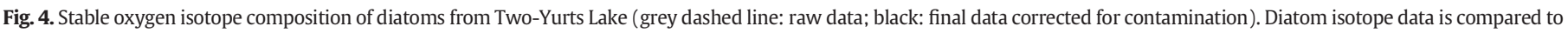

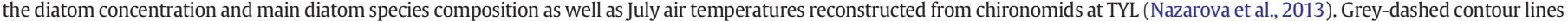
give the reconstructed minimum and maximum $\mathrm{T}_{\text {July. }}$. DAZ are diatom assemblage zones as used in Hoff et al. (this issue).

Hence, we assume the changes in the isotopic composition of the lake water $\left(\delta^{18} \mathrm{O}_{\text {lake }}\right)$ to be the most important control on the $\delta^{18} \mathrm{O}_{\text {diatom }}$ record. The $\delta^{18} \mathrm{O}_{\text {lake }}$ at TYL is mainly influenced by the $\delta^{18} \mathrm{O}_{\text {prec }}$ signal rather than by evaporative effects. Changes in $\delta^{18} \mathrm{O}_{\text {prec }}$ are again linked

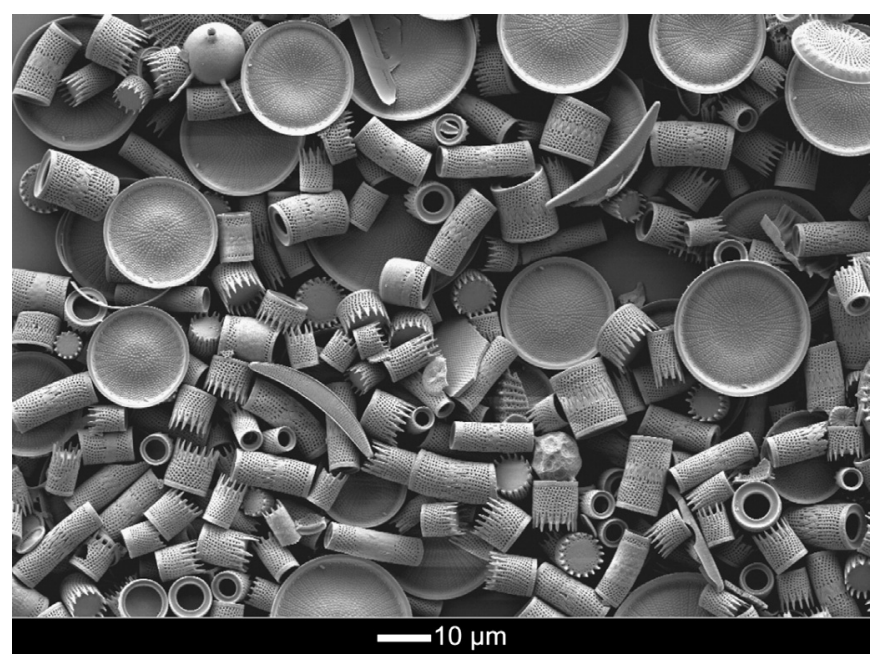

Fig. 5. SEM picture of the purified TYL diatom assemblage. No mineral grains or tephra glass sherds are visible indicative for the high degree of purity of the samples. Main displayed species: Stephanodiscus medius Håkansson (>10 $\mu \mathrm{m})$, Aulacoseira subarctica and $A$. subarctica f. recta Müller (Girdle and valve views; $<10 \mu \mathrm{m}$ ). to either air temperature changes and/or changes in the atmospheric circulation patterns (Leng and Barker, 2006).

\subsection{Implementation of other regional information}

\subsubsection{Chironomids}

Chironomid analyses (Nazarova et al., 2013) at TYL provide additional insight about the likeliness of $\delta^{18} \mathrm{O}_{\text {prec }}$ being the most relevant control for the $\delta^{18} \mathrm{O}_{\text {diatom }}$ record. The application of transfer functions on the fossil chironomid assemblages in sediment cores PG1857-2/-5 yielded an estimate of temporal changes in palaeo July air temperatures $\left(\mathrm{T}_{\text {air July }}\right.$ ) in central Kamchatka in the range of $\sim 2-3{ }^{\circ} \mathrm{C}$ (Fig. 4 and 6 ). The used transfer function was inferred from modern chironomid training data sets from lakes of eastern Siberia (Nazarova et al. 2008, 2011). The chironomid-based $\mathrm{T}_{\text {air July }}$ exhibit a threefold pattern of change with colder intervals $\left(\sim 12-13{ }^{\circ} \mathrm{C}\right)$ before about $3.9 \mathrm{kyr}$ BP and after about $1.2 \mathrm{kyr}$ BP. Between 3.9 and $1.2 \mathrm{kyr}$ BP, the chironomid-based climate reconstruction yielded warmer temperatures $\left(\mathrm{T}_{\text {air July }}>14{ }^{\circ} \mathrm{C}\right)$ (Figs. 4, 6) interrupted by a short cool phase around 2.8 kyr BP visible in both records $\left(\delta^{18} \mathrm{O}_{\text {diatom }}\right.$ and chironomid-based $\left.\mathrm{T}_{\text {air July }}\right)$. Both display a similar overall decreasing trend towards the upper part of the core. Hypothesizing that the decrease in $\delta^{18} \mathrm{O}_{\text {diatom }}$ of about $4.0 \%$ would have been caused solely by changes in $\delta^{18} \mathrm{O}_{\text {prec }}$, this would correspond to a mean annual air temperature (MAAT) decrease of about $3{ }^{\circ} \mathrm{C}$ (Dansgaard, 1964). This is in the same order of magnitude as the chironomid-based temperature reconstruction and could be explained by Late Holocene cooling. 
The lower part of the core, however, shows a decrease in the $\delta^{18} \mathrm{O}_{\text {diatom }}$ record between 4.5 and $3.5 \mathrm{kyr} \mathrm{BP}$ inversely correlated to chironomid $\mathrm{T}_{\text {air July }}$ (Nazarova et al., 2013; Fig. 6). Whereas the chironomid-based $\mathrm{T}_{\text {air July }}$ infers a warming, the $\delta^{18} \mathrm{O}_{\text {diatom }}$ record rather corresponds to decreasing air temperatures for this period. This overall inverse behaviour of both proxy time series can best be explained by changes in water supply from the hinterland to the lake.

\subsubsection{Water supply from the catchment}

Brooks and Birks (2001) describe that $\mathrm{T}_{\text {air July }}$ reconstructions based on chironomids might become critical during periods with increased glacier formation due to a strong increase of the gradient between air temperature and lake water temperatures. Relatively high air temperatures may result in lower lake temperatures because of an increased input of cold meltwaters originating from the hinterland, i.e. glaciers. Then reconstructed $\mathrm{T}_{\text {air July }}$ would indicate a colder regime than it actually has been. Thus, we assume that the reconstructed values of $\mathrm{T}_{\text {air July }}$ for the lower part of the core may be too low.

Additionally, the isotopic composition of an inflow draining into a lake is relatively depleted in heavy isotopes when originating from higher altitudes (e.g. from a spring or a glacier with temporal melting events). The enhanced formation of glaciers could decrease the input of winter precipitation (and relatively increase summer precipitation) into the lake by conserving it within a newly formed glacier. Since summer precipitation has an enriched isotopic composition compared to winter precipitation (Fig. 2), this would shift the $\delta^{18} \mathrm{O}_{\text {lake }}$ to a more positive ('heavier') isotopic composition. This could, at least partly explain the relatively high $\delta^{18} \mathrm{O}_{\text {diatom }}$ values in the older part of the record (Fig. 6). The decrease in $\delta^{18} \mathrm{O}_{\text {diatom }}$ and increasing chironomid-derived $\mathrm{T}_{\text {air July }}$ after 4 kyr would then reflect increased meltwater input until the glaciers - if they existed at this time - were gone. A similar phenomenon with decreasing $\delta^{18} \mathrm{O}_{\text {diatom }}$ due to greater meltwater input from higher altitudes has been described for Lake Kotokel in the Lake Baikal area (Kostrova et al., 2013). The subsequent decrease in $\delta^{18} \mathrm{O}_{\text {diatom }}$ (after $4 \mathrm{kyr} \mathrm{BP}$ ) could be related to melting of the glacier in the hinterland as supported by a simultaneous increase in $\mathrm{T}_{\text {air July }}$ from the chironomid-based reconstruction. We suggest that the glacier advances that Savoskul (1999) described for south Kamchatka at around 5 kyr BP might have included the hinterland of Two-Yurts Lake. Therefore, we assume that changes in the $\delta^{18} \mathrm{O}_{\text {prec }}$ signal are mainly responsible for the general trend in the $\delta^{18} \mathrm{O}_{\text {diatom }}$ record, whereas changes in water supply in the catchment (see Fig. 1; and Hoff et al., this issue) (i.e. from a melting glacier) could reverse and superimpose this pattern.

\subsubsection{Diatom assemblages}

The diatom species composition of Two-Yurts Lake after $4.5 \mathrm{kyr}$ BP extends over four development stages (Hoff et al., this issue). Due to detrital input by tributaries and a well-mixed lake environment, large amounts of silica were permanently available allowing for high biological productivity and high absolute diatom abundances at TYL. During DAZ 2 (4.5 to $3.5 \mathrm{kyr} \mathrm{BP}$ ), a rather cold climate prevailed, dominated by $A$. subarctica, S. minutulus and $S$. medius. This contrasts with the highest $\delta^{18} \mathrm{O}_{\text {diatom }}$ values pointing to rather warm conditions before 3.6 kyr BP. DAZ 3 ( 3.5 to $2.5 \mathrm{kyr}$ BP) displays colder temperatures and a strongly mixed water body (A. subarctica and S. minutulus). The cooling at around $3.6 \mathrm{kyr} \mathrm{BP}$ is also documented in decreasing $\delta^{18} \mathrm{O}_{\text {diatom }}$ values. The interval $\sim 2.5$ to $0.7 \mathrm{kyr} \mathrm{BP}$ (DAZ 4) is characterised by C. ocellata indicative of higher temperatures and/or a thermal stratification of the water column. Even though $\delta^{18} \mathrm{O}_{\text {diatom }}$ maxima are observed at 2.5 and $1.8 \mathrm{kyr} \mathrm{BP}$, the stable isotope record continues to follow the overall cooling trend. The youngest DAZ 5 ( $\sim 0.7 \mathrm{kyr} B P$ to present) is interpreted as a period of cold temperatures (high contents of A. subarctica and S. minutulus; $C$. ocellata lacking) also reflected in the $\delta^{18} \mathrm{O}_{\text {diatom }}$ record. This documents that changes in the diatom assemblages and their respective palaeoenvironmental interpretations do not necessarily correspond to changes in $\delta^{18} \mathrm{O}_{\text {diatom. }}$.

\subsubsection{Palynology}

The spliced record from TYL sediments has been subdivided into four pollen assemblage zones since $4.5 \mathrm{kyr} B \mathrm{BP}$ (compare Hoff et al., this issue; PAZ 4-7). Between 4.5 and $3.3 \mathrm{kyr} \mathrm{BP}$, pollen data indicate a warm and wet climate dominated by stone birch forest (corresponding better to $\delta^{18} \mathrm{O}_{\text {diatom }}$ than DAZ). Between 3.3 and $2.6 \mathrm{kyr} \mathrm{BP}$, white birch forest advanced suggesting drier and/or more continental climate conditions with a maximum forest expansion around ca. $2.7 \mathrm{kyr}$ BP. From 2.6 to $1.3 \mathrm{kyr}$ BP pollen assemblages indicate retreating forests, more moderate temperatures and wetter conditions. Since the beginning of the youngest PAZ starting after $1.3 \mathrm{kyr}$, forest retreated further and shrublands expanded suggesting cooler, but still wet climate conditions. Consequently the overall climate deterioration is also visible in the TYL pollen record, whereas the boundaries of the PAZ do not correspond with marked $\delta^{18} \mathrm{O}_{\text {diatom }}$ changes.

\subsection{The TYL $\delta^{18} O_{\text {diatom }}$ record in the north hemispheric context}

The character of the diatom isotope record obtained for TYL is similar to that obtained for Lake Kotokel (Kostrova et al., 2013), Kola Peninsula (Jones et al., 2004), Lake Baikal (Mackay et al., 2011) and Swedish Lapland (Lake 850: Shemesh et al., 2001). All curves show a general Mid to Late Holocene depletion in $\delta^{18} \mathrm{O}_{\text {diatom }}$ through the cores from $4.5 \mathrm{kyr} \mathrm{BP}$ to the present, which is in line with many other climate reconstructions of the northern hemisphere (Wanner et al., 2008). Ice cores $\delta^{18} \mathrm{O}$ records i.e. from Greenland (N-GRIP; Vinther et al., 2006; Fig. 6) and the Canadian Arctic (Agassiz ice core; Fisher et al., 1995) display decreasing trends throughout the Holocene. Furthermore, palynological climate reconstructions from the Siberian Arctic also show a Mid to Late Holocene cooling trend (Andreev et al., 2001, 2004). The main driver of this Mid to Late Holocene cooling is assumed to be the decreasing summer insolation (Laskar et al., 2004; Fig. 6; 60 $\mathrm{N}$ ). We therefore conclude that the overarching trend in the TYL $\delta^{18} \mathrm{O}_{\text {diatom }}$ record is mainly driven by summer insolation changes. However, besides the overall decrease in $\delta^{18} \mathrm{O}_{\text {diatom }}$ throughout the Mid to Late Holocene, several minor minima and maxima are visible in the TYL record.

The Holocene climate has not been stable as demonstrated in numerous high-resolution palaeoclimate studies (Mayewski et al., 2004; Wanner et al., 2008 and references therein). For the Mid to Late Holocene, Mayewski et al. (2004) identified five periods of significant rapid climate change (RCC) during the time periods of $6-5,4.2-3.8$, $3.5-2.5,1.2-1.0$ and $0.6-0.15 \mathrm{kyr}$ BP, displaying marked changes in temperature and major atmospheric circulation patterns. During several of the RCC phases, the TYL $\delta^{18} \mathrm{O}_{\text {diatom }}$ record shows distinct minima or maxima, i.e. the absolute maximum around $4 \mathrm{kyr}$ BP followed by a strong decrease in $\delta^{18} \mathrm{O}_{\text {diatom }}$ at about $3.7 \mathrm{kyr}$, which might be an evidence of Neoglacial cooling. The absolute minimum at $0.2-0.3 \mathrm{kyr}$ $\mathrm{BP}$ might correspond to the negative climate anomaly known as Little Ice Age (LIA). Hence our record is broadly in line with palaeotemperatures inferred from the GRIP borehole in Greenland (Dahl-Jensen et al., 1998).

A smaller minimum is observed in the TYL $\delta^{18} \mathrm{O}_{\text {diatom }}$ record around $3 \mathrm{kyr}$ BP followed by a maximum around $2.5 \mathrm{kyr}$. The TYL $\delta^{18} \mathrm{O}$ minima around 3.0 (and also 0.3) kyr BP occur in RCC phases of a stronger than normal Siberian High (Mayewski et al., 2004 and references therein; Fig. 6).

Itaki and Ikehara (2004) demonstrated that the position of the two most important air pressure systems for Kamchatka - the Aleutian Low and the Siberian High - directly affect the moisture sources as well as the amount of precipitation. A drastic shift towards a decreasing ventilation of the Okhotsk Sea Intermediate Water (OSIW) was described around $3.5 \mathrm{kyr}$ BP. This shift reflects a change of the relative position between the Aleutian Low and the Siberian High (Itaki and Ikehara, 2004). Before $3.5 \mathrm{kyr}$ BP, the regional air pressure systems were arranged in a north Aleutian Low mode, accompanied by 
enhanced ventilation of the OSIW, warmer temperatures and prevailing northerly winds on Kamchatka. In contrast, the south Aleutian Low mode has been described between 3 and $2 \mathrm{kyr}$ BP and 0.3 to $0.4 \mathrm{kyr}$ $\mathrm{BP}$ and is accompanied by decreased ventilation, colder temperatures and mainly easterly winds. The abrupt change of the air mass origin at $3.5 \mathrm{kyr}$ BP bears the potential to shift $\delta^{18} \mathrm{O}_{\text {prec }}$ and hence $\delta^{18} \mathrm{O}_{\text {lake }}$ and $\delta^{18} \mathrm{O}_{\text {diatom }}$ to lower values in Kamchatka lakes during the south Aleutian Low mode. As a clear shift about $3.5 \mathrm{kyr}$ BP is visible in the Two-Yurts Lake $\delta^{18} \mathrm{O}_{\text {diatom }}$ record (Fig. 6), changes of moisture origin and/or pathways may be at least partly responsible for the $\delta^{18} \mathrm{O}_{\text {diatom }}$ in Kamchatkan lakes.

This is further substantiated by observations from the Yukon region (Anderson et al., 2005). The maximum in TYL $\delta^{18} \mathrm{O}_{\text {diatom }}$ around $2.5 \mathrm{kyr}$ BP corresponds to an eastward shift of the Aleutian Low as indicated by a $\delta^{18} \mathrm{O}$ anomaly in the Jellybean carbonates (Anderson et al., 2005). We hypothesize that the shift in position of the Aleutian Low might have weakened the dominant pressure centre over eastern Asia i.e. in Kamchatka and influenced the regional atmospheric moisture transport.

Furthermore, the TYL diatom $\delta^{18} \mathrm{O}$ record shows similarities to the stalagmite $\delta^{18} \mathrm{O}$ record from Dongge Cave, China (Yuan et al., 2004) such as a marked change around $2.5 \mathrm{kyr}$ BP with a decrease in both $\delta^{18} \mathrm{O}$ records. The $\delta^{18} \mathrm{O}$ records from Chinese stalagmites are interpreted as an indicator of the Pacific monsoon intensity (Tarasov et al., 2009), which weakened since the Mid Holocene. Kamchatka's regional atmospheric moisture transport seems to be influenced by the interplay of the changing conditions in the dominant air pressure centres (Siberian High, Aleutian Low) with TYL $\delta^{18} \mathrm{O}_{\text {diatom }}$ record presumably being indicative of moisture source changes.
In summary, the TYL diatom oxygen isotope record presented in this paper is linked to changes in the northern hemispheric climate, which are responsible for the transport of heat and moisture to Kamchatka. The $\delta^{18} \mathrm{O}_{\text {diatom }}$ record of TYL core shows that the Holocene has been a period of variable climate conditions with an overall Mid to Late Holocene cooling trend likely triggered by summer insolation. Several known Holocene climate features including periods of RCC such as the LIA as well as changing atmospheric pressure conditions are visible as minima/maxima in the TYL record and, hence, might explain parts of the variability in $\delta^{18} \mathrm{O}_{\text {diatom. }}$.

\section{Conclusions}

For reconstructing Holocene climate change, a $\delta^{18} \mathrm{O}_{\text {diatom }}$ record from fossil diatoms from Two-Yurts Lake (Kamchatka, Russia) has been investigated. We used spliced sections of two sediment cores (PG1857-2/PG1857-5) from Two-Yurts Lake, Kamchatka for palaeolimnological investigations also including diatom, pollen and chironomid analyses.

For the most recent diatom sample at TYL (0.2-0.3 kyr BP; $\delta^{18} \mathrm{O}_{\text {diatom }}=+23.3 \%$ o), the isotope fractionation between water and

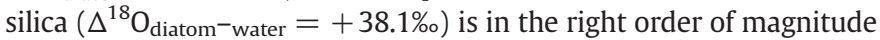
when being related to the isotope composition of recent lake water (mean $\delta^{18} \mathrm{O}_{\text {lake }}=-14.8 \%$ ) and recent water temperature $\left(\sim 10{ }^{\circ} \mathrm{C}\right)$. Nonetheless, the TYL $\delta^{18} \mathrm{O}_{\text {diatom }}$ record is mostly controlled by internal-changes in the isotopic composition of the lake water $\left(\delta^{18} \mathrm{O}_{\text {lake }}\right)$ and hence by air temperature, hydrology and atmospheric circulation pattern changes.

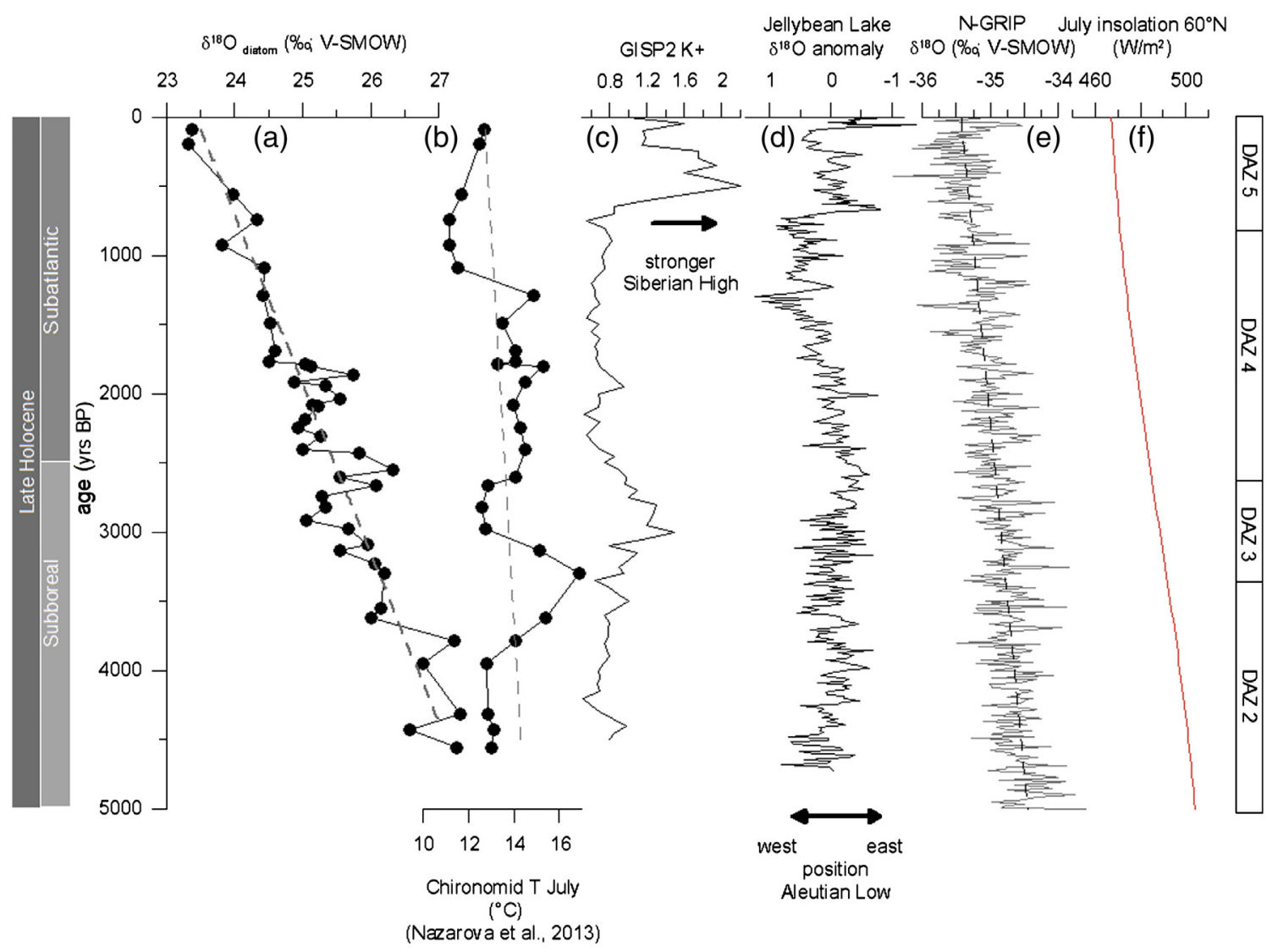

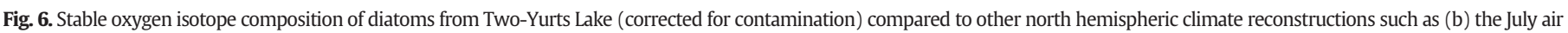

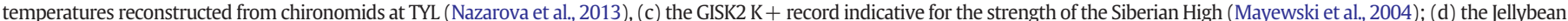

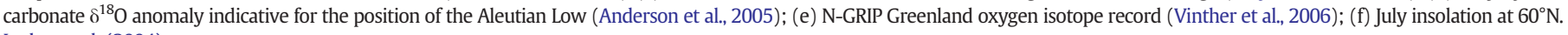
Laskar et al. (2004). 
The downcore $\delta^{18} \mathrm{O}_{\text {diatom }}$ record documents Holocene climate dynamics in Kamchatka. We interpreted an overall decrease in $\delta^{18} \mathrm{O}_{\text {diatom }}$ from $+27.3 \%$ to $+23.3 \%$ between about $\sim 4.5 \mathrm{kyr}$ BP and today as Late Holocene cooling trend. This gross pattern is also detectable in other TYL proxy information from bioindicators (such as diatom assemblage, pollen and chironomid data), and in good accordance with other north hemispheric environmental changes (i.e. a summer insolationdriven Mid- to Late Holocene cooling). Late Holocene climate variability in the TYL $\delta^{18} \mathrm{O}_{\text {diatom }}$ record yields evidence for a Neoglacial cooling starting at $3.7 \mathrm{kyr} \mathrm{BP}$, with the Little Ice Age (LIA) as the coldest phase in the past $4.5 \mathrm{kyr}$.

However, the TYL $\delta^{18} \mathrm{O}_{\text {diatom }}$ record not only reflects global climatic changes but also accounts for local to regional environmental features. The comparison with other bioindicator proxy data (i.e. the chironomid-based lake water temperature record) especially demonstrates the complex interaction of different controls for changing environmental conditions at TYL, Kamchatka. These include site-specific factors such as hydrological changes (i.e. enhanced inflow of snow meltwater) superimposing general, i.e. northern hemisphere climatic trends. Furthermore, the $\delta^{18} \mathrm{O}_{\text {diatom }}$ record is linked with atmospheric-oceanic changes such as the interplay between Siberian High and Aleutian Low air pressure centers, as well as with the sea ice dynamics in the Sea of Okhotsk.

In summary, the interpretation of $\delta^{18} \mathrm{O}_{\text {diatom }}$ data from lacustrine sediments yields important and unique information on past climate and hydrology changes for the remote and sparsely investigated area of Kamchatka, Russia.

\section{Acknowledgements}

This research took place in the frame of the Russian-German KALMAR Project funded by the German Federal Ministry of Education and Research (BMBF Grant 03G0640B). The team of the Kamchatka 2007 expedition group is acknowledged for coring and subsampling. We thank Ute Bastian, Antje Eulenburg and Lutz Schoenicke of the Alfred Wegener Institute for Polar and Marine Research (AWI) for their help in the laboratories. Additional thanks are extended to Helga Kemnitz from the German Research Center for Geosciences (GFZ) for her SEM and EDS support used for diatom contamination assessment as well as to Anson MacKay for the constructive review.

\section{References}

Anderson, L., Abbott, M.B., Finney, B.P., Burns, S.J., 2005. Regional atmospheric circulation change in the North Pacific during the Holocene inferred from lacustrine carbonate oxygen isotopes, Yukon Territory, Canada. Quat. Res. 64, 21-35.

Andreev, A.A., Klimanov, V.A., Sulerzhitsky, L.D., 2001. Vegetation and climate history of the Yana River lowland, Russia, during the last 6400 yr. Quat. Sci. Rev. 20, 259-266.

Andreev, A.A., Tarasov, P., Schwamborn, G., Ilyashuk, B., Ilyashuk, E., Bobrov, A., Klimanov, V., Rachold, V., Hubberten, H.-W., 2004. Holocene paleoenvironmental records from Nikolay Lake, Lena River Delta, Arctic Russia. Palaeogeogr. Palaeoclimatol. Palaeoecol. 209, 197-217.

Battarbee, R.W., Mackay, A.W., Jewson, D.H., Ryves, D.B., Sturm, M., 2005. Differential dissolution of Lake Baikal diatoms: correction factors and implications for palaeoclimatic reconstruction. Glob. Planet. Chang. 46 (1-4), 75-86.

Brandriss, M.E., O'Neil, J.R., Edlund, M.B., Stoermer, E.F., 1998. Oxygen isotope fractionation between diatomaceous silica and water. Geochim. Cosmochim. Acta 62, 1119-1125.

Brewer, T.S., Leng, M.J., Mackay, A.W., Lamb, A.L., Tyler, J.J., Marsh, N.G., 2008. Unravelling contamination signals in biogenic silica oxygen isotope composition: the role of major and trace element geochemistry. J. Quat. Sci. 23 (4), 321-330.

Brooks, S.J., Birks, H.J.B., 2001. Chironomid-inferred air temperatures from Lateglacial and Holocene sites in north-west Europe: progress and problems. Quat. Sci. Rev. 20, 1723-1741.

Chapligin, B., Meyer, H., Friedrichsen, H., Marent, A., Sohns, E., Hubberten, H.-W., 2010. A high-performance, safer and semi-automated approach for the $\delta^{18} \mathrm{O}$ analysis of diatom silica and new methods for removing exchangeable oxygen. Rapid Commun. Mass Spectrom. 24, 2655-2664.

Chapligin, B., Leng, M.J., Webb, E., Alexandre, A., Dodd, J.P., Ijiri, A., Lücke, A., Shemesh, A. Abelmann, A., Herzschuh, H., Longstaffe, F.J., Meyer, H., Moschen, R., Okazaki, Y., Rees, N.H., Sharp, Z.D., Sloane, H.J., Sonzongi, C., Swann, J.E.A., Sylvestre, F., Tyler, J.J., Yam, R.,
2011. Inter-laboratory comparison of oxygen isotope compositions from biogenic silica. Geochim. Cosmochim. Acta 75, 7242-7256

Chapligin, B., Meyer, H., Bryan, A., Snyder, J., Kemnitz, H., 2012a. Assessment of purification and contamination correction methods for analysing the oxygen isotope composition from biogenic silica. Chem. Geol. 300-301, 185-199.

Chapligin, B., Meyer, H., Swann, G.E.A., Meyer-Jacob, C., Hubberten, H.-W., 2012b. A 250 ka oxygen isotope record from diatoms at Lake El'gygytgyn, far east Russian Arctic. Clim. Past 8, 1621-1636. http://dx.doi.org/10.5194/cp-8-1621-2012.

Craig, H., 1961. Isotopic variations in meteoric waters. Science 133, 1702-1703.

Dahl-Jensen, D., Mosegaard, K., Gundestrup, N., Clow, G.D., Johnsen, S.J., Hansen, A.W., Balling, N., 1998. Past temperatures directly from the Greenland Ice Sheet. Science 282, 268-271.

Dansgaard, W., 1964. Stable isotopes in precipitation. Tellus 16, 436-468.

Dirksen, V., Dirksen, O., Diekmann, B., 2013. Holocene vegetation dynamics and climate change in Kamchatka Peninsula, Russian Far East. Rev. Palaeobot. Palynol. 190, 48-65.

Dodd, J.P., Sharp, Z.D., 2010. A laser fluorination method for oxygen isotope analysis of biogenic silica and a new oxygen isotope calibration of modern diatoms in freshwater environments. Geochim. Cosmochim. Acta 74, 1381-1390.

Dodd, J.P., Sharp, Z.D., Fawcett, P.J., Brearley, A.J., McCubbin, F.M., 2012. Rapid postmortem maturation of diatom silica oxygen isotope values. Geochem. Geophys. Geosyst. 13 (9), Q09014.

EPICA Community Members, 2006. One-to-one coupling of glacial climate variability in Greenland and Antarctica. Nature 444, 195-198.

Fisher, D.A., Koerner, R.M., Reeh, N., 1995. Holocene climatic records from Agassiz Ice Cap, Ellesmere Island, NWT, Canada. The Holocene 5 (1), 19-24. http://dx.doi.org/10 1177/095968369500500103.

Gröning, M., Dargie, M., Winckler, G., 2007. Reference sheet for reference materials. Technical Report International Atomic Energy Agency (IAEA).

Hoff, U., Biskaborn, B.K., Dirksen, O., Dirksen, V., Kopsch, C., Meyer, H., Roth, A., Diekmann, B., 2014. Environmental implications from a combined Holocene diatom and pollen study of Two-Yurts Lake (Dvuh-Yurtochnoe) Central Kamchatka, Russia, global and planetary change, (this issue).

Hoff, U., Dirksen, O., Dirksen, V., Herzschuh, U., Hubberten, H.-W., Meyer, H., van den Bogaard, C., Diekmann, B., 2012. Late Holocene diatom assemblages in a lakesediment core from Central Kamchatka, Russia. J. Paleolimnol. 47, 549-560.

Hut, G., 1987. Stable isotope reference samples for geochemical and hydrological investigations. Technical Report. International Atomic Energy Agency.

IAEA/WMO, 2013. Global Network of Isotopes in Precipitation. The GNIP Database (Accessible at: http://www.iaea.org/water).

Itaki, T., Ikehara, K., 2004. Middle to late Holocene changes of the Okhotsk Sea Intermediate Water and their relation to atmospheric circulation. Geophys. Res. Lett. 31, L24309.

Jones, V.J., Leng, M.J., Solovieva, N., Sloane, H.J., Tarasov, P., 2004. Holocene climate of the Kola Peninsula; evidence from the oxygen isotope record of diatom silica. Quat. Sci. Rev. 23, 833-839.

Juillet-Leclerc, A., Labeyrie, L., 1987. Temperature dependence of the oxygen isotopic fractionation between diatom silica and water. Earth Planet. Sci. Lett. 84, 69-74.

Kostrova, S.S., Meyer, H., Chapligin, B., Kossler, A., Bezrukova, E.V., Tarasov, P.E., 2013. Holocene oxygen isotope record of diatoms from Lake Kotokel (southern Siberia, Russia) and its palaeoclimatic implications. Quat. Int. 290-291, 21-34. http://dx.doi.org/10. 1016/j.quaint.2012.05.011.

Krestov, P.V., Omelko, A.M., Nakamura, Y., 2008. Vegetation and natural habitats of Kamchatka. Ber. d. Reinh.- Tüxen-Ges, Hannover. 20, pp. 195-218.

Kurita, N., Yoshida, N., Inoue, G., Chayanova, E.A., 2004. Modern isotope climatology of Russia: a first assessment. J. Geophys. Res. 109 (D03102), 1-15.

Labeyrie, L.J., 1974. New approach to surface seawater paleotemperatures using ${ }^{18} \mathrm{O} /{ }^{16} \mathrm{O}$ ratios in silica of diatom frustules. Nature 248, 40-42.

Lamb, A.L., Brewer, T.S., Leng, M.J., Sloane, H.J., Lamb, H.F., 2007. A geochemical method for removing the effect of tephra on lake diatom oxygen isotope records. J. Paleolimnol. 37, 499-516.

Laskar, J., Robutel, P., Joutel, F., Gastineau, M., Correia, A.C.M., Levrard, B., 2004. A longterm numerical solution for the insolation quantities of the Earth. Astron. Astrophys 428 (1), 261-285. http://dx.doi.org/10.1051/0004-6361:20041335.

Leng, M.J., Marshall, J.D., 2004. Palaeoclimate interpretation of stable isotope data from lake sediment archives. Quat. Sci. Rev. 23, 811-831.

Leng, M.J., Barker, P.A., 2006. A review of the oxygen isotope composition of lacustrine diatom silica for palaeoclimate reconstruction. Earth Sci. Rev. 75, 5-27.

Lisiecki, L.E., Raymo, M.E., 2005. A Pliocene-Pleistocene stack of 57 globally distributed benthic $\delta^{18}$ O records. Paleoceanography 20. http://dx.doi.org/10.1029/2004pa001071.

Mayewski, P.A., Rohling, E.E., Stager, J.C., Karle, W., Maasch, K.A., Meeker, L.D., Meyerson, E.A., Gasse, F., van Kreveld, Sh., Holmgren, K., Lee-Thorp, J., Rosqvist, G., Rack, F. Staubwasser, M., Schneider, R.R., Steig, E.J., 2004. Holocene climate variability. Quat. Res. 62, 243-255.

Mackay, A.W., Swann, G.E.A., Brewer, T.S., Leng, M.J., Morley, D.W., Piotrowska, N., Rioual, P., White, D., 2011. A reassessment of late glacial - Holocene diatom oxygen isotope record from Lake Baikal using a geochemical mass-balance approach. J. Quat. Sci. 26 (6), 627-634.

Meyer, H., Schönicke, L., Wand, U., Hubberten, H.-W., Friedrichsen, H., 2000. Isotope studies of hydrogen and oxygen in ground ice - experiences with the equilibration technique. Isot. Environ. Health Stud. 36, 133-149.

Nazarova, L.B., Pestryakova, L.A., Ushnitskaya, L., Hubberten, H.-W., 2008. Chironomids (Diptera: Chironomidae) in lakes of central Yakutia and their indicative potential for paleoclimatic research. Contemp. Probl. Ecol. 1, 335-345.

Nazarova, L., Herzschuh, U., Wetterich, S., Kumke, T., Pestjakova, L., 2011. Chironomidbased inference models for estimating mean July air temperature and water depth from lakes in Yakutia, northeastern Russia. J. Paleolimnol. 45, 57-71. 
Nazarova, L., de Hoog, V., Hoff, U., Dirksen, O., Diekmann, B., 2013. Late Holocene climate and environmental changes in Kamchatka inferred from subfossil chironomid record. Quat. Sci. Rev. 67, 81-92. http://dx.doi.org/10.1016/j.quascirev.2013.01.018.

Rosqvist, G.C., Rietti-Shati, M., Shemesh, A., 1999. Late glacial to middle Holocene climatic record of lacustrine biogenic silica oxygen isotopes from a Southern Ocean island. Geology 27, 967-970.

Savoskul, O.S., 1999. Holocene glacier advances in the headwaters of Sredniaya Avacha, Kamchatka, Russia. Quat. Res. 52, 14-26.

Schmidt, M., Botz, R., Rickert, D., Bohrmann, G., Hall, S.R., Mann, S., 2001. Oxygen isotopes of marine diatoms and relations to opal-A maturation. Geochim. Cosmochim. Acta 65, 201-211.

Sharp, Z.D., 1990. A laser-based microanalytical method for the in situ determination of oxygen isotope ratios of silicates and oxides. Geochim. Cosmochim. Acta 54 (5), 1353-1357.

Shemesh, A., Charles, C.D., Fairbanks, R.G., 1992. Oxygen isotopes in biogenic silica: global changes in ocean temperature and isotopic composition. Science 256, 1434-1436.

Shemesh, A., Burckle, L.H., Hays, J.D., 1995. Late Pleistocene oxygen isotope records of biogenic silica from the Atlantic sector of the Southern Ocean. Paleoceanography 10 179-196.

Shemesh, A., Peteet, D., 1998. Oxygen isotopes in fresh water biogenic opal - Northeastern US Allerød-Younger Dryas temperature shift. Geophys. Res. Lett. 25, 1935-1938.

Shemesh, A., Rosqvist, G., Rietti-Shati, M., Rubensdotter, L., Bigler, C., Yam, R., Karlen, W., 2001. Holocene climatic change in Swedish Lapland inferred from an oxygen-isotope record of lacustrine biogenic silica. The Holocene 11 (4), 447-454.

Solomina, O., Wiles, G., Shiraiwa, T., D'Arrigo, R., 2007. Multiproxy records of climate variability for Kamchatka for the past 400 years. Clim. Past 3 (119-128). http://dx.doi. org/10.5194/cp-3-119-2007 (2007).
Swann, G.E.A., Leng, M.J., Sloane, H.J., Maslin, M.A., Onodera, J., 2007. Diatom oxygen isotopes: evidence of a species effect in the sediment record. Geochem. Geophys. Geosyst. 8, Q06012. http://dx.doi.org/10.1029/2006GC001535.

Swann, G.E.A., Leng, M.J., Sloane, H.J., Maslin, M.A., 2008. Isotope offsets in marine diatom $\delta^{18} \mathrm{O}$ over the last $200 \mathrm{ka}$. J. Quat. Sci. 23, 389-400.

Swann, G.E.A., Leng, M.J., 2009. A review of diatom $\delta^{18}$ O in palaeoceanography. Quat. Sci. Rev. 28, 384-398.

Tarasov, P.E. Bezrukova, EV V Krivonogov, S.K, 2009. Late Glacial and Holocene changes in vegetation cover and climate in southern Siberia derived from a $15 \mathrm{kyr}$ long pollen record from Lake Kotokel. Clim. Past 5, 285-295.

Vinther, B.M., Clausen, H.B., Johnsen, S.J., Rasmussen, S.O., Andersen, K.K., Buchardt, S.L. Dahl-Jensen, D., Seierstad, I.K., Siggaard-Andersen, M.-L., Steffensen, J.P., Svensson, A.M., Olsen, J., Heinemeier, J., 2006. A synchronized dating of three Greenland ice cores throughout the Holocene. J. Geophys. Res. 111, D13102. http://dx.doi.org/10. 1029/2005JD006921.

Wanner, H., Beer, J., Bütikofer, J., Crowley, T.J., Cubasch, U., Flückiger, J., Goosse, H., Grosjean, M., Joos, F., Kaplan, J.O., Küttel, M., Müller, S.A., Prentice, I.C., Solomina, O., Stocker, T.F., Tarasov, P., Wagner, M., Widmann, M., 2008. Mid- to late Holocene climate change - an overview. Quat. Sci. Rev. 27 (19-20), 1791-1828.

Wetzel, R.G., 2001. Limnology: Lake and River Ecosystems. Academic Press, San Diego and London, p. 1006.

Yuan, D.X., Cheng, H., Edwards, R.L., Dykoski, C.A., Kelly, M.J., Zhang, M.L., Qing, J.M., Lin, Y. S., Wang, Y.J., Wu, J.Y., Dorale, J.A., An, Z.S., Cai, Y.J., 2004. Timing, duration, and transitions of the Last Interglacial Asian monsoon. Science 304, 575-578. 